\title{
Circulating nucleic acids in plasma and serum: applications in diagnostic techniques for noninvasive prenatal diagnosis
}

This article was published in the following Dove Press journal:

International Journal of Women's Health

16 April 2013

Number of times this article has been viewed

\section{Peter B Gahan}

Anatomy and Human Sciences Department, King's College London, London Bridge, London, UK
Correspondence: Peter B Gahan Anatomy and Human Sciences Department, King's College London, London Bridge, London SEI IUL, UK Email pgahan@aol.com, peter.gahan@ kcl.ac.uk

\begin{abstract}
The analysis of fetal nucleic acids in maternal blood 13 years ago has led to the initiation of noninvasive methods for the early determination of fetal gender, rhesus D status, and a number of aneuploid disorders and hemoglobinopathies. Subsequently, a comparatively large quantity of fetal DNA and RNA has been demonstrated in amniotic fluid as well as small amounts in premature infant saliva. The DNA and RNA in amniotic fluid has permitted an analysis of core transcriptomes, whilst the DNA and RNA in saliva allows the early detection and treatment monitoring of fetal developmental problems. These aspects are discussed together with the methodology and limits of analysis for noninvasive prenatal diagnosis in predictive, preventive, and personalized medicine.
\end{abstract}

Keywords: fetal circulating DNA/RNA, amniotic fluid, saliva, aneuploidy, thalassemias

\section{Introduction}

The first demonstration of DNA in human blood more than 60 years ago $^{1}$ was somewhat forgotten in the search for the structure of $\mathrm{DNA}^{2,3}$ and its identification as the gene. ${ }^{4}$ Thus, the presence of nucleic acids in the circulatory system was ignored until high DNA levels were demonstrated in the blood of patients with systemic lupus erythematosus ${ }^{5}$ as well as in cancer. ${ }^{6}$ Subsequent isolation of DNA from the blood of cancer patients showed it to be tumor cell derived. ${ }^{7}$ From such a platform were launched a series of studies analyzing nucleic acids isolated from plasma and serum of patients suffering from a wide spectrum of disorders.

Early studies on circulating nucleic acids demonstrated both DNA and RNA fragments. A review on the general biology of circulating nucleic acids in plasma and serum (CNAPS) has offered a wide range of possible sources for the DNA/RNA. ${ }^{8}$ However fetal nucleic acids in maternal blood are derived primarily from both the fetus and the placenta ${ }^{9-11}$ and, most likely, directly from the fetus in the case of amniotic fluid. ${ }^{12}$ Fetal DNA sequences tend to be short, ${ }^{13,14}$ implying that they are mainly derived by apoptosis rather than by necrosis. ${ }^{8}$ In addition, DNA and RNA sequences have been released from cells either by exocytosis as exosomes or as newly synthesized virtosomes, complexes acting as intercellular messengers. ${ }^{8}$

It is clear that CNAPS can be exploited as an approach for use in predictive, preventive, and personalized medicine. Consequently, studies on CNAPS have tended to fall into three categories; namely (1) fetal nucleic acid analyses and (2) clinical conditions, eg, oncology and diabetes, both areas being underpinned by (3) the study of the basic biology of CNAPS. 
Prenatal screening and diagnosis has been established as a routine way of checking for fetal gender, fetal rhesus $\mathrm{D}(\mathrm{RhD})$, and fetal chromosomal abnormalities including aneuploidies, hemoglobinopathies, Tay-Sachs disease, sickle cell anemia, cystic fibrosis, and fragile $\mathrm{X}$ syndrome. In addition, birth defects and conditions such as spina bifida, cleft palate, and muscular dystrophy have also been screened. The main testing procedures include amniocentesis and chorionic villus sampling (CVS), together with ultrasonography, ultrasound, serum markers, and genetic screening. Each of these methods has a limited sensitivity, each test having a specific window of time for success. Thus, CVS cannot be performed before 9 weeks of gestation, while amniocentesis is normally offered between 15 and 20 weeks. ${ }^{15}$ Both methods carry a risk of fetal loss of $<1.0 \%$. Equally, ultrasonography cannot detect fetal gender during the first trimester. ${ }^{16}$ Thus, a minimally invasive assessment permitting the clarification of fetal gender, $\mathrm{RhD}$, and abnormalities at an early stage of pregnancy was a desirable development.

The concept of the release of nucleic acids into the maternal circulating blood led Dennis Lo's group ${ }^{17}$ to examine the possibility of the presence of fetal DNA/RNA in the maternal blood stream and to its separation and identification from maternal DNA. This has laid the basis for the exploitation of maternal peripheral blood as a source of fetal DNA and RNA for use as a noninvasive prenatal testing (NIPT) method for determining fetal gender, blood genotyping, aneuploid disorders, $\beta$-thalassemia, complete fetal genome sequencing, and the likelihood of pre-eclampsia onset. These aspects and the methodologies involved form the basis of the following review, together with a consideration of the ethics of the use of NIPT for early diagnosis of fetal disorders.

\section{Fetal DNA/RNA in maternal CNAPS, amniotic fluid, and premature infant saliva DNA in CNAPS}

Although fetal nucleated red blood (NRBC) cells have been demonstrated to be present in the maternal circulation, ${ }^{18,19}$ they have not yet proved a success for NIPT. However, using an erythroblast scoring system based on the morphological and hemoglobin-staining characteristics of these cells, together with an analysis of inherited DNA polymorphisms, has allowed a distinction to be made between NRBCs of maternal and fetal origin, independently of fetal gender. ${ }^{20}$

Fetal cells in the maternal circulation also have been examined as possible sources of genetic information for noninvasive prenatal diagnosis. However, their small numbers present in maternal blood has limited their use in the routine genetic determination of fetal abnormalities. ${ }^{21}$ A subsequent multicenter clinical project aimed at noninvasive methods of prenatal diagnosis was developed (National Institute of Child Health and Human Development Fetal Cell Isolation Study - NIFTY). The initial objective was to assess fluorescence in situ hybridization (FISH) analysis of interphase nuclei of fetal cells from maternal blood as compared with metaphase karyotypes of fetal cells obtained by either amniocentesis or CVS. ${ }^{22}$ Although cell isolation and FISH analysis protocol differences between centers occurred, the blinded and pooled data led to a fetal gender detection rate of $41.4 \%$. The detection rate for finding a minimum of one aneuploid cell for fetal aneuploidy was $74.4 \%$. False positives for gender were $11.1 \%$ while that for aneuploidy were $0.6 \%-4.1 \%$. This study was based on detection of a single fetal cell in nearly all cases, which together with the lack of a reliably determined false-positive rate for detecting aneuploidy, made strict improvements a necessity if this method should have a future use. ${ }^{22}$

The alternative approach, of using fetal DNA/RNA present in the maternal blood, by Lo et $\mathrm{al}^{17}$ rested upon the identification of $Y$ chromosome fragments, ie, the paternal male determining chromosome that would not be present in the mother's X chromosome DNA. This approach was confirmed by Smid et $\mathrm{al}^{23}$ and Houfflin-Debarge et al. ${ }^{24}$ Employing a more sensitive real-time polymerase chain reaction (PCR) technique to amplify and measure the amounts of DNA, Lo et $\mathrm{al}^{25}$ were able to increase the sensitivity close to $100 \%$ for the identification of fetal-derived Y-chromosomal sequences from maternal plasma and serum. They also showed that the fetal DNA was present in high concentrations in maternal plasma, reaching a mean of 25.4 genome equivalents $\mathrm{mL}^{-1}$ (range 3.3-69.4) in early pregnancy and 292.2 genome equivalents $\mathrm{mL}^{-1}$ (range 76.9-769.0) in late pregnancy, ie, $3.40 \%$ (range $0.39 \%-11.90 \%$ ) and $6.20 \%$ (range $2.33 \%-11.40 \%$ ) of the total plasma DNA in early and late pregnancy, respectively. Thus, the absolute concentration of fetal DNA in maternal serum increased with gestational age, disappearing rapidly following birth, with a mean half-life of 16.3 minutes. ${ }^{26}$ Degraded fetal DNA has been detected in maternal urine, using massively parallel paired-end sequencing, becoming lost after birth. ${ }^{27}$

Fetal DNA can be identified since it tends to be $<300$ base pairs (bp) in size and can be distinguished from maternal DNA, which is essentially $>300 \mathrm{bp}$ in size. The median percentages of plasma DNA with size $>201$ bp were $57 \%$ in pregnant women and $14 \%$ in nonpregnant women, with median percentages of fetal DNA in maternal plasma of 
sizes $>193$ bp and $>313$ bp being $20 \%$ and $0 \%$, respectively. The NIPT methods using CNAPS results in initial amounts of fetal DNA from 2 to $5 \mathrm{~mL}$ of maternal blood being very small, hence it is necessary to increase the amount of DNA - and RNA - if a successful analysis of fetal DNA/RNA is to be made in relation to diagnosis, prognosis, and treatment monitoring. This is usually effected by the various forms of PCR whereby thousands to millions of copies of a specific DNA sequence are generated from either a single or a few copies of a piece of DNA/RNA. One of the most effective approaches is that of quantitative real-time PCR (qRT-PCR) whereby the targeted DNA sequence is simultaneously amplified and quantified. RNA can also be amplified in this way using reverse-transcription PCR (RT-PCR).

Since the first studies of fetal DNA in CNAPS, technology has moved on apace with the development of secondgeneration sequencing tools or massively parallel sequencing. This encompasses several high-throughput approaches to DNA sequencing that became commercially available from about 2005. There are a number of such systems available using miniaturized and parallelized platforms for sequencing of $1-100$ million short reads (50-400 bases). PCR is performed externally to the machines as part of the library preparation. However, within the machine, PCR of the DNA/ RNA increases the amount of nucleic acid available for the sequencing step. Thus, both PCR and sequencing processes are performed in the same instrument, reducing the chances of contamination as well as increasing the speed and accuracy of analysis. This has permitted a larger-scale production of genomic sequences, including an increasing number of human genome sequences. ${ }^{28-31}$

Thus, the way has been opened for more rapid and detailed analyses of CNAPS in terms of diagnosis, ${ }^{32} \mathrm{eg}$, through the more ready identification of single nucleotide polymorphisms (SNPs).

Lo et $\mathrm{al}^{33}$ used paired-end massively parallel sequencing to study the genomic sequence and size distribution of fetal DNA in maternal plasma. They constructed a genomewide genetic fetal map and a mutational profile of the fetus from maternal plasma DNA sequences, together with data concerning the paternal genotype and maternal haplotype. They suggested further that this minimally invasive process could be exploited for a prenatal, genome-wide scanning to determine fetal genetic disorders. The employment of an alternative approach of direct shotgun high-through-put sequencing ${ }^{33,34}$ has permitted the full fetal genome to be derived by mapping and enumerating the fragments relative to the chromosome of origin. Counting the number of sequence tags mapped to each chromosome allows the detection of over- or underrepresentation of any chromosome in maternal plasma DNA contributed by an aneuploid fetus. ${ }^{34,35}$ A major advantage of this method is that it does not need the differentiation between fetal versus maternal DNA. Using large tag counts, the method can be applied to arbitrarily small fractions of fetal DNA. This approach for sequencing the full fetal genome was based upon the concept that within each pair of parental haplotypes, the transmitted haplotype is overrepresented relative to the nontransmitted one. Hence, measurement of the relative amount of parental haplotypes by counts of the number of alleles specific to each parental haplotype permits the inheritance of each parental haplotype to be deduced and, therefore, the building of the complete fetal genome. However, before using shotgun sequencing, the counting principle was applied directly to each allele in the fetal exome by performing exome capture on maternal plasma DNA. Thus, exome screening, of clinically relevant and deleterious alleles that were either paternally inherited or had arisen as de novo germ-line mutations, was determined. Such an analysis, combined with that of shotgun sequencing, offers a relatively comprehensive study of the fetal genome and so is a more reliable approach to NIPT.

\section{DNA in amniotic fluid}

Most studies of DNA have been made on plasma and serum. However, with the availability of amniotic fluid after its clinical diagnostic use, Hui and Bianchi were able to demonstrate that its cell free DNA content was present at concentrations higher $\left(100-200\right.$-fold $\left.\mathrm{mL}^{-1}\right)$ than that observed in plasma. It is comprised essentially of fetal DNA and represents a separate pool of cell free DNA to that of the maternal plasma. ${ }^{36}$ The first application of amniotic fluid DNA involved comparative genomic hybridization (CGH) microarray analysis using GenoSensor Array 300, which permitted the identification of fetal sex and whole chromosome gains or losses, eg, trisomy 21 and monosomy $\mathrm{X}^{37}$ Using CGH array analysis of amniotic fluid DNA from 13 fetuses with congenital abnormalities, Miura et a ${ }^{38}$ were able to correctly identify 12 fetuses with chromosomal losses or gains. A false-negative result occurred with a fetus having a balanced translocation, 45, XY, der(14;21)(q10;q10).

\section{RNA}

Male-specific mRNA was first described by Poon et $\mathrm{al}^{39}$ in maternal plasma from pregnant women carrying male fetuses by using a two-step RT-PCR assay. Y-chromosome-specific zinc finger protein $(Z F Y)$ mRNA and human leucocyte antigen 
(HLA-G) mRNA were specifically identified, the total amounts of messenger RNA (mRNA) increasing with increasing time of pregnancy.

RNA present in plasma and serum is very stable, ${ }^{40}$ even though Reddi and Holland ${ }^{41}$ have demonstrated the presence of RNase in serum at an average amount of 104 units $\mathrm{mL}^{-1}$. The RNAs tend to be found in a particulate form, with the RNA appearing to be protected by a membrane, eg, released from healthy cells in exosomes or together with lipoprotein complexes as virtosomes. However, RNA can be derived also by either apoptosis or necrosis. ${ }^{8,42}$

The majority of studies have examined mRNAs from uniquely expressed placental genes, eg, human placental lactogen, ${ }^{40} \beta$ subunit of human placental chorionic gonadotropin, ${ }^{40}$ corticotrophin releasing hormone, ${ }^{43}$ and glia cell missing-1 mRNA. ${ }^{44}$ Such RNAs originate primarily from the syncytiotrophoblast rather than, as expected, from the maternal circulation. ${ }^{40}$

\section{RNA in amniotic fluid}

Although most studies of RNA have been made on plasma and serum, as with DNA, cell free RNA has been shown to be present in amniotic fluid. ${ }^{45,46}$ The RNA data are of interest in that the cell free RNAs are derived almost exclusively from the embryo.

An in-silico study by Hui et $\mathrm{al}^{47}$ has identified 476 well annotated genes in the amniotic fluid from euploid midtrimester amniotic fluid samples. Six physiological systems were represented in the amniotic fluid core transcriptome. These included the development and function of the musculoskeletal and nervous system plus embryonic and organismal development. A key canonical pathway identified was that of the mammalian target of rapamycin signaling. Of the 23 highly organ-specific transcripts identified, six were known to be highly expressed in the fetal brain. Although the obtention of amniotic fluid is an invasive procedure, this approach does permit the identification of fetal defects for which clinical management could commence in utero.

\section{RNA in saliva}

Many infants are born prematurely worldwide each year, resulting in very high annual health care costs, often due to severe medical sequelae. To develop NIPT biomarkers to detect disorders early so as to initiate treatment, Maron et $\mathrm{al}^{48}$ developed a method for the isolation and identification of RNAs from the saliva of premature infants. Using saliva RNA amplification and hybridization onto whole genomic microarrays together with bioinformatic analyses, they were able to demonstrate 9286 gene transcripts showing statistically significant gene expression changes across individuals over time, with $37.9 \%$ genes being downregulated and $62.1 \%$ genes upregulated. The gene expression changes were closely linked to developmental pathways. As might be expected, the downregulated expression was related to embryonic development, connective tissue, and hematological system development and function. However, significantly upregulated genes included those linked to behavior and the development of the nervous system, tissue, organ, and digestive system. This NIPT approach offers the screening of premature infants with a small volume of saliva $(50-200 \mu \mathrm{L})$ that can be taken at successive times from any one infant, so allowing possible treatment to be instigated and monitored.

\section{Fetal gender}

Fetal gender determination has been performed on fetal DNA in maternal blood using either paternal derived fragments of the Y chromosome ${ }^{17,23,49}$ or paternal X-chromosome derived fragments of the amelogenin gene and multicopy DAZ sequence. ${ }^{50}$ The main method for gender determination is based upon the presence or absence of the Y-chromosome sequences $D Y S 14, D A Z$, and $S R Y$, ie, they will only be present in male-bearing pregnancies. ${ }^{51}$ Tang et al ${ }^{52}$ have identified paternally inherited X-chromosomal microsatellite polymorphisms in the plasma of pregnant women carrying female fetuses. Similarly, Chen et $\mathrm{al}^{53}$ have demonstrated monosomy and disomy paternal $10 \mathrm{q}$ by two informative markers, D10S534 and D10S186 in maternal blood. These show the possibility for detection of female fetuses. However, most routine hospital and private clinic tests are based upon the presence or absence of Y-chromosome markers.

\section{Rhesus status}

A rhesus (Rh)-negative mother carrying an Rh-positive fetus may develop antibodies against the Rh antigen if fetal blood enters her bloodstream. If she subsequently becomes pregnant with an Rh-positive fetus, antibodies may cross the placental barrier resulting in hemolytic disease of the newborn. In a Caucasian population, there is deletion within the RHD gene, whilst in $\angle 80 \%$ of the African population, the phenotype is caused by a nonfunctional copy of the $R H D$ gene, RHDpsi, the RHD pseudogene. ${ }^{54}$

Fetal DNA can also be used for fetal blood group genotyping with the Rh status of the fetus being determined. The earliest studies came from Lo et $\mathrm{al}^{55}$ using fluorescence PCR and an RHD sequence, and Bischoff et al ${ }^{56}$ also using a 99 bp DNA fragment specific for the RHD gene and a 
$113 \mathrm{bp}$ fragment specific for the RHCE gene as control. However, the detection level was somewhat low. Detection levels were significantly improved when Finning et $\mathrm{al}^{57}$ used qRT-PCR with the $R, H D$ exons 4,5 , and 10 . Such a technique, with an accuracy of $>99 \%$, was used in a study of eight females to detect $\mathrm{Rh}$ status when incorporating SRY and eight biallelic polymorphisms as internal positive control to avoid the inadequacies of the PCR. There are strong indications for the successful identification of other blood types including Rhc, Rhe, K, and FY..$^{57,58}$ Finning et $a l^{59}$ have introduced a word of caution in using this approach since, for example, only a $95.7 \%$ accuracy was achieved in separating Rh-negative and Rh-positive fetuses in a group of 1997 pregnant women These workers also considered that high throughput $R H D$ genotyping of fetuses in all RHD-negative women could substantially reduce the unnecessary administration of anti-RhD immunoglobulin to $\mathrm{RhD}$-negative pregnant women carrying an $\mathrm{RhD}$-negative fetus. More recently, using quantitative PCR on plasma DNA for the detection of Rh exons 5 and 7, Cardo et al ${ }^{60}$ reported $93 \%$ specificity and $100 \%$ sensitivity, with a $97 \%$ diagnostic accuracy, from a cohort of $111 \mathrm{RhD}$-negative, first-trimester, pregnant women. High levels of detection of RhD-negative carriers were made by Sedrak et $\mathrm{al}^{61}$ using RT-PCR, with $93.5 \%$ and $91.1 \%$ sensitivity and diagnostic accuracy, respectively, in the first trimester and increasing to $100 \%$ and $97.78 \%$, respectively, in the second trimester. Bombard et $\mathrm{a}^{62}$ studied two cohorts: (1) with a serotype reference (11-13 weeks gestation) and (2) with a reference source (6-30 weeks gestation) using matrix-assisted laser desorption/ionization time-of-flight mass spectrometry. Transforming growth interacting factor (TGIF)-like X/Y; AJ427749; (referred to as TGIF) is a human-specific DNA homology block mapping to Yp11.2/Xq21.3 and represents the major shared region between the $\mathrm{X}$ and $\mathrm{Y}$ chromosomes. ${ }^{63}$ Only samples showing the presence of a well defined spectral peak for TGIF were utilized to determine the presence or absence of $R H D$ exons 4, 5, and 7 as well as a 37-bp insertion of exon 4 indicating the psi-pseudogene. In addition, the study included three Y-chromosome sequences, $S R Y, D B Y$, and TTTY2. The presence of all three $\mathrm{RhD}$ exonspecific markers allowed classification as $\mathrm{RhD}$ positive. The sample was called $\mathrm{RhD}$ negative when either one or none of the three exon sequences was detected, whilst the presence of only two sequences was inconclusive. The occurrence of the psi-insertion exon 4 insertion indicated the psi $(+) / R H D$ variant. The serotype $\mathrm{RhD}$ reference cohort showed correct classification for 201/207 patients with a test accuracy and a sensitivity and specificity for prediction of RhD serotype of $97.1 \%, 97.2 \%$, and $96.8 \%$, respectively. The genotype RHD reference cohort showed correct classification in 198/199 patients to yield a test accuracy, specificity, and sensitivity for prediction of $\mathrm{RhD}$ genotype of $99.5 \%, 98.3 \%$, and $100.0 \%$, respectively.

\section{Aneuploidy}

After the first use of NIPT, attempts were made to address the identification of aneuploid situations, and in particular, trisomy 21 (Down's syndrome). If this was successful, it was presumed that the methodology could also be applied to other trisomies, eg, 18 (Edwards syndrome) and 13 (Patau syndrome). Short tandem repeats (STRs) are useful in the determination of the male or female origin of the extra chromosome and, if maternal in origin, its derivation from either meiosis I or meiosis II. ${ }^{64}$ The analysis of the DNA isolated from both peripheral blood and amniotic fluid was compared with results from karyotyping. The STRs employed for diagnosis were D21S11, D21S1413 for trisomy 21, D18S51 for trisomy 18, and D13S631 and D13S258 for trisomy 13. There was a good correlation between the trisomies identified by karyotyping and STRs. Other chromosome 21 STRs used in such studies include S100/BR/BP, D21S167F/R/P, and IGFIF/R/P. ${ }^{65,66}$ Additional approaches have been reviewed by Lo and $\mathrm{Chiu}^{67}$ and by Go et al. ${ }^{68}$ Currently, there are a few remaining as potential NIPT tests. One concerns the exploitation of differentially methylated DNA immuno-precipitation (MeDIP) in conjunction with qRT-PCR ${ }^{69,70}$ For each chromosome analyzed, these workers identified $>2000$ regions of differential methylation between maternal whole blood and placental DNA including a subset of differentially methylated regions. Moreover, $56 \%-83 \%$ of the regions located to nongenic regions, with only $1 \%-11 \%$ overlapping with $\mathrm{CpG}$ (cytosine and guanine phosphodiester bonds) islands. Using this approach for trisomy 21 , correct diagnosis was achieved for 14/14 trisomy 21 cases and 26 controls (normal).

However, the more robust approach appears to lay with the use of high-throughput shotgun sequencing technology. Thus Fan et al, ${ }^{34}$ studying 18 normal and aneuploid pregnancies, were able to identify nine cases of trisomy 21 , two of trisomy 18 , and one of trisomy 13 , with detection being made as early as the 14th week of gestation. This was achieved through sequencing an average of about 10 million 25-bp sequence tags per blood sample. About half of the reads mapped specifically to the human genome to cover about $4 \%$ of the complete genome. An average of circa 154,000 sequence tags mapped to chromosome 13 , circa 135,000 to chromosome 
18 , and circa 65,700 to chromosome 21 . Although few cases were studied, the approach looks very positive.

An alternative approach was adopted by Chiu et $\mathrm{al}^{71}$ in which assays were made for trisomy 21 by combining samples from more than one donor to improve accuracy and also to speed up the rate of analysis of clinical samples. Thus, a unique synthetic DNA "barcode" of 6 bp (an index) was attached to one end of each plasma DNA molecule per donor to act as a signature for each maternal plasma sample. Hence, eight different indices will be needed for each of the eight test or control samples being massively parallel co-sequenced (8-plex sequencing). The experiment compared the pooling of either eight or two maternal plasma DNA preparations (8-plex or 2-plex sequencing). Measurement of the percentage of plasma DNA derived from chromosome 21 was more precise using the 2-plex protocol rather than the 8-plex protocol, with seven times more plasma DNA molecules being identified in the former case. Some trisomy 21 fetuses remained unidentified by the 8-plex protocol but were detected using the 2-plex protocol. The number of plasma DNA molecules analyzed per sample seems to improve the sensitivity of the sequencing. Although trisomy 18 and trisomy 13 were considered by this method, the approach for them appeared to need modifying. The multiplexing approach was also used by Ehrich et al, ${ }^{72}$ with 39 trisomy 21 samples correctly classified and one sample misclassified as trisomy 21 from an original 449 samples assayed. Sensitivity of $100 \%$ and specificity of $99.7 \%$ were claimed.

More recently, a multicenter study, the MELISSA (MatErnal BLood IS Source to Accurately diagnose fetal aneuploidy) study, was made by Bianchi et $\mathrm{al}^{73}$ on 532 samples. They reported successful identification of 89/89 trisomy 21 cases, 35/36 trisomy 18 cases, and 11/14 trisomy 13 cases, with an additional two cases of trisomy 20 (defects in various organs and intrauterine growth retardation) and trisomy 16 (most common chromosomal cause of miscarriages). The overall study was much broader than those described above, including correct analyses for XXX, XXY, and $\mathrm{XYY}$, as well as mosaicism for three cases of trisomy 21 , one case of trisomy 18 , three cases of translocation trisomy, and 2/7 cases of monosomy X. This study shows not only support for the abovementioned trisomy analyses but the possibilities of extending NIPT to a broader range of abnormalities. In a study on twin pregnancies,${ }^{74}$ massively parallel shotgun sequencing was performed upon 25 high-risk pregnancies in a blinded test, where 17 were euploid, five discordant, and two concordant for Down's syndrome. One was also discordant for trisomy 13 , whilst there were two euploid triplet pregnancies. All pregnancies were correctly diagnosed with seven trisomy 21 , one trisomy 13 , and 15 normal twin and two normal triplet pregnancies, ie, there were no false-positives. This confirms the ability to use DNA sequencing of maternal plasma to identify Down's syndrome and other trisomies in multiple gestations.

In two papers by Palomaki et al, ${ }^{75,76}$ trisomy 21,18 , and 13 were studied in a blinded, nested case-control study of a cohort of 4664 pregnancies at high risk for Down's syndrome. A laboratory-developed test based upon next generation sequencing in which there was an adjustment of chromosome counts for guanine-cytosine base content was used. For trisomy 21 in 212 Down's syndrome and 1484 matched euploid pregnancies, the detection level was 209/212 (98.6\%), with 3/1471 (0.02\%) false-positives. The 13 failed tests $(0.8)$ were all euploid. In the case of trisomy 18 (62 pregnancies) and 13 (12 pregnancies), the detection levels were 59/59 and 11/12, respectively, with false-positive levels being $0.28 \%$ and $0.97 \%$, respectively. In a study of trisomy 18 and 21 , Norton et $\mathrm{al}^{77}$ used assays previously described ${ }^{78,79}$ that employ ligation of locus-specific oligonucleotides to yield sequencing templates from only specific genomic loci. This resulted in a reduction in the DNA sequencing required. All 81 trisomy 21 cases were considered high risk for trisomy 21 , with one false-positive from 2888 normal cases, yielding a sensitivity of $100 \%$ and a $0.03 \%$ false-positive level. A total of $37 / 38$ trisomy 18 cases were considered high risk, with two false-positives from 2888 normal pregnancies, giving a sensitivity of $97.4 \%$ and a $0.07 \%$ false-positive level.

\section{Hemoglobinopathies}

\section{$\beta$-thalassemia}

$\beta$-thalassemia is a common autosomal recessive singlegene disorder causing severe anemia through mutations in the $\beta$-globulin gene. One of these mutations, namely, the deletion of four nucleotides (-CTTT) at codons $41 / 42$, was studied by Chiu et al.$^{80}$ Noninvasively, the fetal genotype was completely concordant with conventional analysis and $\beta$-thalassemia major was excluded in the case of two pregnancies. Prenatal detection of $\beta$-thalassemia is also feasible with fetal DNA isolated from the maternal blood using an allelespecific based RT-PCR method. ${ }^{81,82}$ A successful analysis was made with eleven paternally inherited SNPs having a high degree of heterozygosity from the $\beta$-globulin gene for the diagnosis of $\beta$-thalassemia. Papassava et al ${ }^{83}$ have also successfully developed a NIPT method for $\beta$-thalassemia using Solexa high throughput sequencing technology, which 
is based on the combined use of the microchip technology and a single nucleotide base extension method. Using four SNPs of the $\beta$-globin gene, the paternally inherited alleles of the fetus were detected in eight out of ten maternal plasma samples, confirming the CVS analysis.

\section{$\alpha 0$-thalassemia}

An alternative approach has been adopted by Yan et a ${ }^{84}$ for the less studied $\alpha 0$-thalassemia based upon an approach exploited by Ho et al ${ }^{85,86}$ Nondeleted paternally inherited fetal alleles in cases of $\mathrm{Hb}$ Bart's syndrome were identified using microsatellite markers within deletion (--SEA) breakpoints that involved detecting paternal SNPs with deletion breakpoints for NIPT exclusion of monozygous $\alpha 0$-thalassemia. For $\alpha 0$-thalassemia, Yan et $\mathrm{al}^{84}$ considered 16 SNPs, three of which were novel. Using g. $31921 \mathrm{~T}>\mathrm{C}$ as a marker, examination of 65 potential cases showed a correct identification of either the presence $(n=33)$ or absence $(n=30)$ of the normal paternal allele, with two cases unresolved due to blood transport incidents.

\section{Other single-gene disorders}

Fetal nucleic acid methods have been devised to tackle a number of other disorders involving single-gene mutations. However, often the method has been devised and tested on only a very small number of cases (Table 1).

\section{Pre-eclampsia}

Fetal nucleic acids may also be exploited in the early identification of pregnant women who risk developing pre-eclampsia with SRY (that triggers male embryonic development) and DYS (DNA Y-chromosome segment) sequences as markers (reviewed in Sifakis et $\mathrm{al}^{95}$ ). Using the DYS marker, Sifakis et a $1^{95}$ found higher average amounts ( 95.5 genome equivalents $\mathrm{mL}^{-1}$ ) in early pre-eclampsia than late pre-

Table I Diseases for which NIPTs have been devised using fetal nucleic acid from maternal blood

\begin{tabular}{|c|c|c|}
\hline Disease & Gene/mutation & References \\
\hline Achondroplasia & GII38A of FGFR3 gene & 87,88 \\
\hline Cystic fibrosis & Paternal inherited Q890X & 89 \\
\hline Hemophilia & $\begin{array}{l}\text { F8 gene c. } 6278 \mathrm{~A}>\mathrm{G}, \\
\text { c.826G }>\text { A, c. II IIC }>\mathrm{T} \\
\text { F9 gene c.874delC, c. II } 44 \mathrm{~T}>\mathrm{C} \text {, } \\
\text { c. } 802 \mathrm{~T}>\mathrm{A}, \mathrm{c} .1069 \mathrm{G}>\mathrm{A}\end{array}$ & 90 \\
\hline $\begin{array}{l}\text { Huntington } \\
\text { disease }\end{array}$ & $\begin{array}{l}\text { IT-I5 gene } \\
\text { Expanded trinucleotide (CAG) }\end{array}$ & 91 \\
\hline $\begin{array}{l}\text { Myotonic } \\
\text { dystrophy }\end{array}$ & $\begin{array}{l}\text { DMPK gene } \\
\text { Unstable CTG trinucleotide repeat }\end{array}$ & 92,93 \\
\hline $\begin{array}{l}\text { Sickle cell } \\
\text { anemia }\end{array}$ & $\begin{array}{l}\text { HBB gene } \\
\text { Mutant (hemoglobin S) alleles }\end{array}$ & 94 \\
\hline
\end{tabular}

eclampsia (50.8 genome equivalents $\mathrm{mL}^{-1}$ ). Higher levels of $\beta$-globulin and SRY genes were also found in pregnant mothers who developed pre-eclampsia and intrauterine growth retardation. ${ }^{96} \mathrm{~A}$ different approach was used by Chim et al ${ }^{97}$ who showed that the hypermethylated DNA was derived from the maternal blood cells, whilst the hypomethylated form was of fetal origin. Normally, the hypomethylated form is cleared from pregnant women's blood, but about a sixfold increase occurred in the case of pre-eclampsia. However, the SRY gene and DYS markers are strictly of Y-chromosomal origin, and so only male fetus carriers can be diagnosed. RNA also may be used as an early marker of pre-eclampsia. ${ }^{98}$ The fetus-specific circulating mRNA for corticotrophin-releasing hormone increases tenfold, such increases relating to the severity of the pre-eclampsia. Significant downregulation of miRNA 325 has also been reported for pregnancies complicated by pre-eclampsia (median: 0.069 versus $0.101 ; P<0.003)$. Lázár et al ${ }^{99}$ suggested that miRNA 325 expression could indicate a possible role in protein expression changes in pre-eclampsia.

\section{Ethical considerations}

Currently, ethical considerations concern only present-day NIPT methods. ${ }^{100}$ However, the fetal genome can be sequenced ${ }^{32,34}$ and SNPs identified as has already occurred for the human genome with a possible SNP every 100-300 bp, ie, 10-30 million potential SNPs per genome. Given the identification of SNPs prior to birth and subsequent genome sequencing of individuals, fetal diagnostic processes can be employed more generally in predictive, preventive, and personalized medicine. Determining fetal gender and $\mathrm{Rh}$ is of less concern, but with increasingly sensitive methodology being developed, the wide selection of possible disorders identified, eg, through SNPs, will increase the ethical problems. The presence or absence of particular SNPs or DNA sequences that might lead to the development of a clinical disorder does not necessarily mean that the disorder will develop, so leading to uncertainties. How will such medical records be stored and how safe will they be? Who will have access to such information? Who will pay for such analyses and the upkeep of data bases, especially in the absence of a national health service. Can insurance companies demand access to such information, and if yes, how will they exploit the information? Such questions need urgent debate.

\section{Conclusion}

The exciting developments in prenatal diagnosis already permit the analyses of fetal gender, $\mathrm{Rh}$ factor, and some fetal clinical disorders at early stages of fetal development, as well as the onset of pre-eclampsia. A number of these tests 
are already available through national health services and the private sector. Increasing sophistication of the analytical methods, both those available and in development, should ensure an extension of fetal NIPT.

However, with different approaches on offer, it is important that there is quality control and assurance in order for both the routine success of the procedures and reassurance for the parents involved. A start has been made by some working groups, eg, Legler et al. ${ }^{101}$ In addition, in the USA, the main accreditation organizations for molecular laboratories standards and guidelines for molecular testing are the US Food and Drug Administration, Clinical Laboratory Improvement Amendments, the American College of Medical Genetics, and the College of American Pathologists. In Europe, EuroGentest ${ }^{102}$ and the SAFE network (Special Advances in Fetal and neonatal Evaluation network of excellence) [http:// safenoe.org/cocoon/safeorg/] have taken on this task. In the UK, this aspect is covered by RAPID (Reliable, Accurate Prenatal non-Invasive Diagnosis) ${ }^{103}$ and the United Kingdom National External Quality Assessment Service. ${ }^{104}$

Nevertheless, there is still much to be accomplished in the field that is now up to speed in the search for NIPT markers.

\section{Disclosure}

The author reports no conflict of interest in this work.

\section{References}

1. Mendel P, Métais P. Les acides nucleiques du plasma sanguine chez 1'homme. [Nucleic acids in human blood plasma]. C R Acad Sci Paris. 1948;142:241-243. French.

2. Watson JD, Crick FHC. A Structure for deoxyribose nucleic acid. Nature. 1953;171:737-738.

3. Wilkins MFH, Stokes AR, Wilson HR. Molecular structure of deoxypentose nucleic acids. Nature. 1953;171:738.

4. Sinsheimer RL. First Steps toward a genetic chemistry. Science. 1957;125:1123-1128.

5. Koffler D, Agnello V, Winchester R, et al. The occurrence of single stranded DNA in the serum of patients with systemic lupus erythematosus and other diseases. J Clin Invest. 1973;52:198-204.

6. Leon SA, Shapiro B, Sklaroff D, et al. Free DNA in the serum of cancer patients and the effect of therapy. Cancer Res. 1977;37:646-650.

7. Stroun M, Anker P, Maurice P, et al. Neoplastic characteristics of the DNA found in the plasma of cancer patients. Oncology. 1989;46:318-712.

8. Gahan PB, Stroun M. The biology of circulating nucleic acids in plasma and serum. In: Rykova EY, Kikuchi Y, editors. Extracellular Nucleic Acids. In NAMB series "Nucleic Acids and Molecular Biology". Berlin: Springer; 2010.

9. Wataganara T, LeShane ES, Chen AY, et al. Plasma gamma-globulin gene expression suggest that fetal hemapoietic cells contribute to the pool of circulating cell-free fetal nucleic acids during pregnancy. Clin Chem. 2004;50:689.

10. Wataganara T, Leshane ES, Chen AY, et al. Circulating cell-free fetal nucleic acids may be a model marker of fetomaternal hemorrhage after elective first $=$ trimester termination of pregnancy. Ann N Y Acad Sci. 2004;1022:129-134.
11. Lo YMD. Towards the development of noninvasive prenatal diagnosis of fetal chromosomal aneuploidies. Ann N Y Acad Sci. 2008;1137:140-143.

12. Bianchi DW, Leshane ES, Cowan JM. Large amounts of cell-free fetal DNA are present in amniotic fluid. Clin Chem. 2001;47: 1867-1869.

13. Chan KCA, Zhang J, Hui ABY, et al. Size distributions of maternal and fetal DNA in maternal plasma. Clin Chem. 2004;50:88-92.

14. Li Y, Zimmermann B, Rusterholz B, et al. Size separation of circulatory DNA in maternal plasma permits ready detection of fetal DNA polymorphisms. Clin Chem. 2004;50:1002-1011.

15. American College of Obstetricians and Gynecologists. ACOG Practice Bulletin No 88, December 2007. Invasive prenatal testing for aneuploidy. Obstet Gynecol. 2007;110:1459-1467.

16. Odeh M, Granin V, Kais M, et al. Sonographic fetal sex determination. Obstet Gynecol Surv. 2009;64:50-57.

17. Lo YMD, Corbetta N, Chamberlain PF, et al. Presence of fetal DNA in maternal plasma and serum. Lancet. 1997;350:485-487.

18. Walknowska J, Conte FA, Grumbach MM. Practical and theoretical implications of fetal/maternal lymphocyte transfer. Lancet. 1969;1:1119-1122.

19. Lo YMD, Patel P, Wainscoat JS, et al. Prenatal sex determination by DNA amplification from maternal peripheral blood. Lancet. 1989;2:1363-1365.

20. Cha DH, Khosrotehrani K, Bianchi DW, et al. The utility of an erythroblast scoring system and gender-independent short tandem repeat (STR) analysis for the detection of aneuploid fetal cells in maternal blood. Prenat Diagn. 2005;25:586-591.

21. Bianchi DW. Fetal cells in the maternal circulation: feasibility for prenatal diagnosis [Review]. Br J Haematol. 1999;105:574-583.

22. Bianchi DW, Simpson JL, Jackson LG, et al. Fetal gender and aneuploidy detection using fetal cells in maternal blood: analyses of NIFTY I data. Prenatal Diag. 2002;22:609-615.

23. Smid M, Lagona F, de Benassuti L, et al. Evaluation of different approaches for fetal DNA analysis from maternal plasma and nucleated blood cells. Clin Chem. 1999;45:1570-1572.

24. Houfflin-Debarge V, O'Donnell H, Overton T, et al. High sensitivity of fetal DNA in plasma compared to serum and nucleated cells using unnested PCR in maternal blood. Fetal Diagn Ther. 2000;15: 102-107.

25. Lo YMD, Tein MSC, Lau TK, et al. Quantitative analysis of fetal DNA in maternal plasma and serum: implications for noninvasive prenatal diagnosis. Am J Hum Genet. 1998;62:768-775.

26. Lo YM, Zhang J, Leung TN, et al. Rapid clearance of fetal DNA from maternal plasma. Am J Hum Genet. 1999;64:218-224.

27. Tsui NBY, Jiang P, Chow KCK, et al. High resolution size analysis of fetal DNA in the urine of pregnant women by paired-end massively parallel sequencing. PLoS One. 2012;7:e48319.

28. Korbel JO, Urban AE, Affourtit JP, et al. Paired-end mapping reveals extensive structural variation in the human genome. Science. 2007;318:420-426.

29. Kidd JM, Cooper GM, Donahue WF, et al. Mapping and sequencing of structural variation from eight human genomes. Nature. 2008;453:56-64.

30. Levy S, Sutton G, Ng PC, et al. The diploid genome sequence of an individual human. PLoS Biol. 2007;5:e254.

31. Wang J, Wang W, Li R, et al. The diploid genome sequence of an Asian individual. Nature. 2008;456:60-65.

32. Lo YMD, Chiu RWK. Plasma nucleic acid analysis by massively parallel sequencing: pathological insights and diagnostic implications. J Path. 2011;25:318-323.

33. Lo YMD, Chan KCA, Sun H, et al. Maternal plasma DNA sequencing reveals the genome-wide genetic and mutational profile of the fetus. Sci Transl Med. 2010;2:61ra91.

34. Fan HC, Blumenfeld YJ, Chitkara U, et al. Noninvasive diagnosis of fetal aneuploidy by shotgun sequencing DNA from maternal blood. Proc Natl Acad Sci U S A. 2008;105:16266-16271. 
35. Fan $\mathrm{C}, \mathrm{Gu} \mathrm{W}$, Wang J, et al. Non-invasive prenatal measurement of the fetal genome. Nature. Epub August 18, 2012.

36. Hui L, Bianchi DW. Cell-free fetal nucleic acids in amniotic fluid. Hum Reprod Update. 2011;17:362-371.

37. Larrabee PB, Johnson KL, Pestova E, et al. Microarray analysis of cell-free fetal DNA in amniotic fluid: a prenatal molecular karyotype. Am J Hum Genet. 2004;75:485-491.

38. Miura S, Miura K, Masuzaki H, et al. Microarray comparative genomic hybridization (CGH)-based prenatal diagnosis for chromosome abnormalities using cell-free fetal DNA in amniotic fluid. J Hum Genet. 2006;51:412-417

39. Poon LLM, Leung TN, Lau TK, et al. Presence of fetal RNA in maternal plasma. Clin Chem. 2000;46:1832-1834.

40. Ng EK, Tsui NB, Lau TK, et al. mRNA of placental origin is readily detectable in maternal plasma. Proc Natl Acad Sci U S A. 2003; 100:4748-4753.

41. Reddi KK, Holland JF. Elevated serum ribonuclease in patients with pancreatic cancer. Proc Natl Acad Sci U S A. 1976;73:2308-2310

42. Gahan PB, Stroun M. The virtosome - a novel cytosolic informative entity and intracellular messenger. Cell Biochem Funct. 2010;28:529-538.

43. Ng EK, Leung TN, Tsui NB, et al. The concentration of circulating corticotropin-releasing hormone mRNA in maternal plasma is increased in preeclampsia. Clin Chem. 2003;49:727-731.

44. Go AT, Visser A, Mulders MA, et al. Detection of placental transcription factor mRNA in maternal plasma. Clin Chem. 2004;50 1413-1414.

45. Larrabee PB, Johnson KL, Lai C, et al. Global gene expression analysis of the living human fetus using cell-free messenger RNA in amniotic fluid. J Am Med Assoc. 2005;293:836-842.

46. Slonim DK, Koide K, Johnson KL, et al. Functional genomic analysis of amniotic fluid cell-free mRNA implies that oxidative stress is significant in Down syndrome fetuses. Proc Natl Acad Sci U S A. 2009;106:9425-9429.

47. Hui L, Slonim DK, Wick HC, et al. The amniotic fluid transcriptome: a source of novel information about human fetal development. Obstet Gynecol. 2012;119:111-118.

48. Maron JL, Johnson KL, Rocke DM, et al. Neonatal salivary analysis reveals global developmental gene expression: changes in the premature infant. Clin Chem. 2010;56:409-416.

49. Vainer OB, Katokhin AV, Khustov SM, et al. A new Y chromosome marker for non-invasive fetal gender determination. Ann NY Acad Sci. 2008;1137:157-161.

50. Vecchione G, Tomaiuolo M, Sarno M, et al. Fetal identification in maternal plasma by means of short tandem repeats on chromosome $\mathrm{X}$ Ann N Y Acad Sci. 2008;1137:148-156.

51. Wright CF, Burton H. The use of cell-free fetal nucleic acids in maternal blood for non-invasive prenatal diagnosis. Hum Reprod Update. 2009;15:139-151.

52. Tang NLS, Leung TN, Zhang J, et al. Detection of fetal-derived paternally inherited X-chromosome polymorphisms in maternal plasma. Clin Chem. 1999;45:2033-2035.

53. Chen C-P, Chern S-R, Wang W. Fetal DNA analyzed in plasma from a mother's three consecutive pregnancies to detect paternally inherited aneuploidy. Clin Chem. 2001;47:937-939.

54. Ghorbian S. Applications of cell free fetal DNA in maternal serum. Int $J$ Fertility Fetal Med. 2012;3:33-39.

55. Lo YM, Hjelm NM, Fidler C, et al. Prenatal diagnosis of fetal RhD status by molecular analysis of maternal plasma. $N$ Engl $J$ Med 1998;339:1734-1738.

56. Bischoff FZ, Nguyen DD, Marquéz-Do D, et al. Noninvasive determination of fetal RhD status using fetal DNA in maternal serum and PCR. J Soc Gynecol Investig. 1999;6:64-69.

57. Finning K, Martin P, Daniels G. A clinical service in the UK to predict fetal Rh (Rhesus) D blood group using free fetal DNA in maternal plasma. Ann N Y Acad Sci. 2004;1022:119-124.

58. Daniels G, Finning K, Martin P, et al. Fetal blood group genotyping. Present and future. Ann N Y Acad Sci. 2006;1075:88-95.
59. Finning K, Martin P, Summers J, et al. Effect of high throughput RHD typing of fetal DNA in maternal plasma on use of anti-RhD immunoglobulin in RhD negative pregnant women: prospective feasibility study. BMJ. 2008;336:816-826.

60. Cardo L, Garcia BP, Alvarez FV. Non-invasive fetal $R D H$ genotyping in the first trimester of pregnancy. Clin Chem Lab Med. 2010;48: 1121-1126.

61. Sedrak L, M, Hashad D, Adel H, et al. Use of free fetal DNA in prenatal noninvasive detection of fetal $\mathrm{RhD}$ status and fetal gender by molecular analysis of maternal plasma. Genet Test Mol Biomarkers. 2011;15:627-631.

62. Bombard AT, Akolekar R, Farkas DH, et al. Fetal RHD genotype detection from circulating cell-free fetal DNA in maternal plasma in nonsensitised RhD negative women. Prenat Diagn. 2011;31:802-828.

63. Akolekar R, Farkas DH, VanAgtmael AL, et al. Fetal sex determination using circulating cell-free fetal DNA (ccffDNA) at 11 to 13 weeks of gestation. Prenat Diagn. 2010;30:918-923.

64. Kotzol D, Bundscherer G, Bernasconi F, et al. Isochromosome 18P results from maternal meiosis-II nondisjunction. Eur J Hum Genet. 1996;4:168-174

65. Yang YH, Kim IK, Oh SH, et al. Rapid prenatal diagnosis of trisomy 21 by polymerase chain reaction associated analysis of small tandem repeats and S100B in chromosome 21. Fetal Diagn Ther. 1998;13:361-366.

66. Yang YH, Nam MS, Yang ES. Rapid prenatal diagnosis of trisomy 21 by real-time quantitative polymerase chain reaction with amplification of small tandem repeats and S100B in chromosome 21. Yonsei Med J. 2005;46:193-197.

67. Lo YMD, Chiu RWK. Noninvasive prenatal diagnosis of fetal chromosome aneuploidies by maternal plasma nucleic analysis. Clin Chem. 2008;54:461-466.

68. Go AT, van Vugt JM, Oudejans CB. Non-invasive aneuploidy detection using free fetal DNA and RNA in maternal plasma: recent progress and future possibilities. Hum Reprod Update. 2011;17:372-382.

69. Papageorgiou EA, Fiegler H, Rakyan V, et al. Sites of differential DNA methylation between placenta and peripheral blood: molecular markers for noninvasive prenatal diagnosis of aneuploidies. Am J Pathol. 2009;174:1609-1618.

70. Papageorgiou EA, Karagrigoriou A, Tsaliki E, et al. Fetal-specific DNA methylation ratio permits noninvasive prenatal diagnosis of trisomy 21 . Nat Med. 2011;17:510-513.

71. Chiu RWK, Akolakar R, Zheng YWL, et al. Non-invasive prenatal assessment of trisomy 21 by multiplexed maternal plasma DNA sequencing: large scale validity study. BMJ. 2011;342:c7401.

72. Ehrich M, Dsciu C, Zwieelhofer T, et al. Noninvasive detection of fetal trisomy 21 by sequencing of DNA in maternal blood: a study in a clinical setting. Am J Obstet Gynecol. 2011;204:205-208.

73. Bianchi DW, Platt LD, Goldberg JD, et al; MatErnal BLood IS Source to Accurately diagnose fetal aneuploidy (MELISSA) Study Group. Genome-wide fetal aneuploidy detection by maternal plasma DNA sequencing. Obstet Gynecol. 2012;119:890-901.

74. Canick JA, Kloza EM, Lambert-Messerlian GM, et al. DNA sequencing of maternal plasma to identify Down syndrome and other trisomies in multiple gestations. Prenat Diagn. 2012;32:730-734.

75. Palomaki GE, Kloza EM, Lambert-Messerlian GM, et al. DNA sequencing of maternal plasma to detect Down syndrome: an international clinical validation study. Genet Med. 2011;13:913-920.

76. Palomaki GE, Deciu C, Kloza EM, et al. DNA sequencing of maternal plasma reliably identifies trisomy 18 and trisomy 13 as well as Down syndrome: an international collaborative study. Genet Med. 2012;14:296-305.

77. Norton ME, Brar H, Weiss J, et al. Non-Invasive Chromosomal Evaluation (NICE) study: results of a multicenter prospective cohort study for detection of fetal trisomy 21 and trisomy 18. Am J Obstet Gynecol. 2012;207:137. e1-e8.

78. Sparks A, Wang E, Struble C, et al. Selective analysis of cell-free DNA in maternal blood for evaluation of fetal trisomy. Prenat Diagn. 2012;32:1-7. 
79. Sparks AB, Struble CA, Wang E, et al. Noninvasive prenatal detection and selective analysis of cell-free DNA obtained from maternal blood: evaluation for trisomy 21 and trisomy 18. Am J Obstet Gynecol. 2012;206:319. e1-e9.

80. Chiu RW, Lau TK, Leung TN, et al. Prenatal exclusion of beta thalassaemia major by examination of maternal plasma. Lancet. 2002;360:998-1000.

81. Papasavva T, Kalikas I, Kyrri A, et al. Noninvasive prenatal diagnostic assay for the detection of $\beta$-thalassemia. Ann N Y Acad Sci. 2006;107:148-153.

82. Papasavva T, Kalikas I, Kyrri A, et al. Arrayed primer extension for the noninvasive prenatal diagnosis of $\beta$-thalassemia based on detection of single nucleotide polymorphisms. Ann N Y Acad Sci. 2008;1137:302-330.

83. Papassava T, van Eicken W, Kockx C, et al. High throughput sequencing enables non-invasive prenatal diagnosis of beta thalassemia using SNPs. J Nucleic Acids Invest. 2011;2:5-6.

84. Yan T-Z, Mo Q-H, Cai R, et al. Reliable detection of paternal SNPs within deletion breakpoints for non-invasive prenatal exclusion of homozygous $\alpha^{0}$-thalassemia in maternal plasma. PLoS One. 2011;6:e24779.

85. Ho SS, Chong SS, Koay ES, et al. Microsatellite markers within --SEA breakpoints for prenatal diagnosis of HbBarts hydrops fetalis. Clin Chem. 2007;53:173-179.

86. Ho SS, Chong SS, Koay ES, et al. Noninvasive prenatal exclusion of haemoglobin Bart's using foetal DNA from maternal plasma. Prenat Diagn. 2010;30:65-73.

87. Li Y, Page-Christiaens CG, Gille JJ, et al. Non-invasive prenatal detection of achondroplasia in size-fractionated cell-free DNA by MALDITOF MS assay. Prenat Diagn. 2007;27:11-17.

88. Lim JHL, Kim MJ, Kim SY, et al. Non-invasive prenatal detection of achondroplasia using circulating fetal DNA in maternal plasma. J Assist Reprod Genet. 2011;28:167-172.

89. González-González MC, Garcia-Hoyos M, Trujillo MJ, et al. Prenatal detection of a cystic fibrosis mutation in fetal DNA from maternal plasma. Prenat Diag. 2002;22:946-948.

90. Tsui NBY, Kadir RA, Chan KCA, et al. PCR analysis of maternal plasma DNA Noninvasive prenatal diagnosis of hemophilia. Blood. 2011;117:3684-3691.

91. González-González MC, Garcia-Hoyos M, Trujillo-Tiebas MJ, et al. Improvement in strategies for the non-invasive prenatal diagnosis of Huntington disease. J Assist Reprod Genet. 2008;25:477-481.
92. Amicucci P, Gennarelli M, Novelli G, et al. Prenatal diagnosis of myotonic dystrophy using fetal DNA obtained from maternal plasma. Clin Chem. 2000;46:301-302.

93. Bonifazi E, Gullotta F, Vallo L, et al. Use of RNA fluorescence in situ hybridization in the prenatal molecular diagnosis of myotonic dystrophy type I. Clin Chem. 2006;52:319-322.

94. Barrett AN, McDonnell TCR, Chan KCA, et al. Digital PCR analysis of maternal plasma for noninvasive detection of sickle cell anemia. Clin Chem. 2012;58:1026-1032.

95. Sifakis S, Zaravinos A, Maiz N, et al. First-trimester maternal plasma cell-free fetal DNA and preeclampsia. Am J Obstet Gynecol. 2009;201:472. e1-e7.

96. Swaminathan R, Butt A. Circulating nucleic acids in plasma and serum: recent developments. Ann NY Acad Sci. 2006;1075:1-9.

97. Chim SS, Tong YK, Chiu RW, et al. Detection of the epigenetic signature of the maspin gene in maternal plasma. Proc Natl Acad Sci U S A. 2005;102:14753-14758.

98. Wong BC, Chiu RW, Tsui NB, et al. Circulating placental RNA in maternal plasma is associated with a preponderance of $5^{\prime}$ mRNA fragments: implications for non-invasive prenatal diagnosis and monitoring. Clin Chem. 2005;51:1786-1795.

99. Lázár L, Nagy B, Morvarec A, et al. The correlation of circulating cell-free DNA, cell-free fetal DNA and microRNA 325 levels to clinical characteristics and laboratory parameters in pre-eclampsia. In: Gahan PB, editor. Circulating Nucleic Acids in Plasma and Serum. Berlin: Springer; 2010:155-158.

100. Deans Z, Hill M, Chitty LS, et al. Non-invasive prenatal testing for single gene disorders: exploring the ethics. Eur J Hum Genet. Epub November 28, 2012.

101. Legler TJ, Mavrou A, Finning K, et al. Workshop report on the extraction of foetal DNA from maternal plasma. Prenat Diagn. 2007;27:824-829.

102. EuroGentest [homepage on the Internet]. Available from: http://www. eurogentest.org. Accessed March 19, 2013.

103. RAPID [homepage on the Internet]. Available from: http://www.rapid. nhs.uk. Accessed March 19, 2013.

104. UK NEQAS [homepage on the Internet]. Available from: http://www. ukneqas.org.uk. Accessed March 19, 2013.
International Journal of Women's Health

\section{Publish your work in this journal}

The International Journal of Women's Health is an international, peerreviewed open-access journal publishing original research, reports, editorials, reviews and commentaries on all aspects of women's healthcare including gynecology, obstetrics, and breast cancer. The manuscript management system is completely online and includes
Dovepress

a very quick and fair peer-review system, which is all easy to use. Visit http://www.dovepress.com/testimonials.php to read real quotes from published authors. 